\title{
Formulation and In-vivo study of Nanoparticle of Babandotan (Ageratum conyzoides $L$ ) Leaves Extract Gel on Osteoarthritis model rat
}

\author{
Anton Bahtiar ${ }^{1}$, Deantari Karliana ${ }^{1}$, Dian Agustina ${ }^{1}$, Iskandarsyah Iskandarsyah ${ }^{2}$, Effionora Anwar $^{2}$ \\ ${ }^{I}$ Department of Pharmacology and Toxicology, Faculty of Pharmacy, Universitas Indonesia, Indonesia, ${ }^{2}$ Department of \\ Pharmaceutics, Faculty of Pharmacy, Universitas Indonesia, Indonesia Affiliation 2, Indonesia
}

Rheumatoid arthritis (RA) is an autoimmune disease charactherized by chronic inflammation in joints. Ageratum conyzoides L. (Babandotan) leaves are proven to be used in inflammation therapy. The proper formulation should be done to assure that the content of the extract reach to the synsythium where the inflammation occurs.

This study aimed to increase the skin penetration of Quercetin in ethanolic extract of Ageratum conyzoides L. leaves by incorporate it into nanoparticle system as a vehicle and generally applied to gel preparations. Babandotan leaves extract nanoparticle were formulated with different extract concentration which are 0.04\% (F1), 1.2\% (F2), and 2\% (F3). Nanoparticle with the best characteristic then was formulated into gel preparations. Extract gel of nonnanoparticle was made as a control. We used 36 male rats Sprague Dawley strain divided into 6 groups. Normal group was given $0.5 \%$ of $\mathrm{CMC}$, the negative control group was given $0.025 \mathrm{ml}$ of sodium iodoacetate in $0.9 \%$ saline, positive groups control group was given a sodium diclofenac gel and three doses of Babandotan gel. Based on the result, F3 had the best characteristic with spherical morphology, Z-Average value at $107.3 \mathrm{~nm}$, polydispersity index at 0.613 , zeta potential at $-36.22+/-3.83$ $\mathrm{mV}$, and highest percentage of drug entrapped efficiency $(42.51+/-0.52 \%)$. The application of gel to the osteoarthritis rat model showed best progress compare with negative control and showed the similar result to the positive control. Based on these result, it can be concluded that the nanoparticle gel had better penetration compared with the gel and nanoparticle system could increase the skin penetration capability of quercetin in babandotan leaves extract. 